\title{
2018 年度専門領域研究活動報告
}

\section{体育哲学}

\section{研究誌の発行}

誌名：体育哲学年報（第 49 号）

発行年月日：平成 31 年 3 月 31 日

\section{学会賞等の授与}

学会賞

（※論文題目等：受賞者の氏名・所属）

高島平三郎『体育原理』における用語「体育」の 意味分析

佐々木究 (山形大学)

\section{浅田学術奨励賞}

運動部活動における体罰の意味論

松田太希（中国地域）

\section{○研究会・講演会}

$\bigcirc$ 第 1 回定例研究会

日程: 平成 30 年 6 月 2 日

会場：お茶の水女子大学

演題：授業としての「体育哲学」の可能性

高橋徹（仙台大学）

演題 : 体育哲学専門領域の近未来

深澤浩洋 (筑波大学)

\section{$\bigcirc$ 夏期合宿研究会}

日程：平成 30 年 7 月 14 日一 16 日

会場 : 箱根「静雲荘」

体育学における指導概念の思想的基礎に関する検 討：キルパトリックの教育学を中心として

石川智貴 (東海大学体育学研究科), 阿部悟

郎 (東海大学)

身体活動における「際に立つ経験」の理論化に向 けて

神野周太郎 (東京学芸大学)

暴力指導の超克へ向けたスポーツ科学の定位

高尾尚平（日本体育大学大学院）

「オリンピック休戦賛同サインの壁」の可視化と
教育的活用

多本直文（首都大学東京オープンユニバーシ ティ)

自己との競争における倫理学考察

金峻現（日本体育大学大学院）

競技者の友愛論 : 競争相手との人間関係に着目し て

佐藤洋 (明星大学)

大学院生による研究小報告とディスカッション $(2$ 名）

森山果保 (筑波大学研究生), 本並健太 (筑 波大学大学院)

Physical education and physical activity of Slovenian children in the context of pedagogical and philosophical perspectives

Joca Zurc（ヨツア ズルツ）（日本学術振興会 外国人特別研究員)

体育専攻の学生に教養としての哲学を教えること （の困難さ）について

関根正美（日本体育大学）

『哲学する』ための基礎要件 : 若き哲学徒に向け $\tau$

佐藤臣彦（茨城地域）

「意味生成」の意味:「生成」としての「身体教育」

久保正秋（スポーツ\&レジャー研究所）

身体活動の科学と運動の実践に関するパラダイム の構築について

石川旦（東京地域）

体育・スポーツ事象をめぐる本質観取の試み

深澤浩洋 (筑波大学)

「実践の中の知」に基づく最適化能力の育成

高橋浩二（長崎大学）

\section{第 2 回定例研究会}

日程: 平成 30 年 12 月 8 日

会場：日本体育大学

無心に依る体育 : その方法

照屋太郎（神奈川地域） 
聖火リレーの記録と記憶：1964 年東京大会関連 資料を対象に

荒牧亜衣（仙台大学）

スポーツにおける社交の可能性：ジンメル『社交 の社会学』

釜崎太 (明治大学)

$「 2018$ IAPS in Oslo, Norway」参加報告

佐藤洋 (明星大学)

○第 3 回定例研究会

日程：平成 31 年 3 月 2 日

会場：日本体育大学

体育学における指導概念の教育学的基礎に関する 検討：キルパトリックの教育学を中心として

石川智貴（東海大学大学院）

広島東洋カープの神話分析：「市民球団」は何を 生成したか

二宮清純（スポーツジャーナリスト）

武道の教育論序説

佐藤雄哉（国士舘大学大学院）

博士論文とその後

松田太希（中国地域）

バレーボールにおける体罰・暴力問題の解決を目 指して

松田太希 (中国地域), 加藤敦志（日本バレ

ーボール協会)

\section{体育史}

\section{研究誌の発行}

誌名：体育史研究（36 号）

発行年月日：2019年 3 月 31 日

\section{○学会賞等の授与}

（※論文の題目 : 受賞者の氏名・所属

\section{体育史学会学会賞（若手研究奨励賞）}

近代武道・合気道の形成過程：植芝盛平の大東流 合気柔術の修行過程に着目して，体育史研究 35 , 27-42.

工藤龍太

\section{研究会・講演会}

体育史学会第 7 回大会

日程：2018 年 5 月 12 - 13 日

会場：中京大学

\section{$\bigcirc$ 研究報告}

武道教員の資格取得状況：埼玉県にみる武徳会称

号（教士，錬士）の取得状況との比較

古川修

武道教員養成校における卒業生の就職先に関する 研究：各学校の卒業生名簿を中心に

佐藤宏拓穣（柏木学園高等学校）

明治後期における英国田園都市構想の日本への伝 播と「間時利導」に関する研究:西欧のレジャー・ レクリエーション計画・施設の日本への受容をめ ぐって

川村若菜（福岡教育大学大学院）

国際バドミントン連盟初期による国際的な運営の 確立（1934-1939 年）

鵤木千加子 (甲南大学)

植民地樺太のスポーツ：『樺太日日新聞』から捉 える植民地におけるスポーツの一側面

冨田幸祐（日本体育大学オリンピックスポー ツ文化研究所）

東京パラリンピック大会（1964）の記録映画

崎田嘉寛（広島国際大学）

○研究方法セミナー

蹴鞠口伝書読解方法について:江戸初期蹴鞠書『中 撰実又記』研究から地下外郎派蹴鞠復元へ向けて 村戸弥生（石川工業高等専門学校）

\section{○そ他}

\section{1）2018 年度体育史学会研究助成}

標記研究助成への申請 4 件について,「体育史 学会研究助成規程」および「体育史学会研究助成 施行細則」にもとづいて審議し, 次の 2 件を研究 助成（各 10 万円）の対象とした。

麦媛（国士舘大学大学院）「香港における 1964 年 第 18 回オリンピック競技大会（東京）に関す る報道と認識」

藤川和俊（帝京平成大学）「日本の体操科におけ る「技術」習得をめぐる問題」

2）「秩父宮記念スポーツ博物館・図書館の機能 
の存続を求める要望書」の提出

7 月 31 日に日本スポーツ体育健康科学学術連 合の代表者とともに, スポーツ庁の鈴木大地長官 と独立行政法人日本スポーツ振興センターの大東 和美理事長を訪問し，「秩父宮記念スポーツ博物 館・図書館の機能の存続を求める要望書」を手渡 した。

\section{体育社会学}

\section{研究誌の発行}

誌名：日本体育学会第 68 回大会 体育社会学専門 領域 発表論文集（第 26 号）

発行年月日：2018 年 8 月 6 日

\section{学会賞等の授与}

体育社会学専門領域学生研究奨励賞 （※論文題目等：受賞者の氏名・所属）

障がい者スポーツにおける障がい者と健常者間の 関係性の変容過程に関する研究—車椅子ソフトボ ールチーム内の相互作用に着目して一：

中村真博（立教大学大学院）

\section{研究会・講演会}

○日本体育学会第 69 回大会体育社会学専門領域 企画シンポジウム

日程：2018 年 8 月 25 日（土） 9:00 11:50

会場：徳島大学三島キャンパス 4 号館 301

テーマ：体育の未来予想図と社会学的想像力

司会 : 菊幸一（筑波大学）

コンピテンシー育成と身体性一OECD/Education2030 における議論を踏まえて一

白井俊（文部科学省）

運動部活動の展望一制度設計なき活動の現状から 考える一

内田良 (名古屋大学)

人工知能時代の体育と遊び一『生きることを面白 くする力』の創造一

松田恵示 (東京学芸大学)

日本体育学会第 69 回大会体育社会学専門領域 研究会
日程：2018 年 8 月 23 日（土） 13:00 16:00

会場：とくぎんトモニプラザ会議室 2

テーマ：教員の働き方改革におけるスポーツ活動 の問題と保健体育教師のアイデンティティ

司会：高橋義雄（筑波大学体育系）

コメンテーター：北村尚浩（鹿屋体育大学体育学 部), 原祐一（岡山大学教育学部)

運動部活動の指導者は何を語ってきたのか?

下竹亮志（筑波大学体育系）

部活動と総合型地域スポーツクラブの連携『失敗』 からみえた教員文化

谷口勇一（大分大学教育学部）

学校のスポーツ活動が地域や社会空間に与える影 響と教師の社会的機能

石坂友司（奈良女子大学生活環境学部）

\section{その他}

新機関誌「年報 体育社会学」は 2020 年 3 月 創刊する予定で準備を進めている。

\section{体育心理学}

\section{研究誌の発行}

誌名：体育心理学専門領域会報（30 巻）

発行年月日：平成 30 年 7 月 20 日

\section{研究会・講演会}

日本体育学会第 69 回大会体育心理学専門領域 シンポジウム

日程：平成 30 年 8 月 25 日

会場 : 徳島大学

テーマ：「ともにあるき, ともにわらう：協調と 共感のダイナミクス」

司会：工藤和俊（東京大学）

指定討論者：木島章文 (山梨大学)

1. 集団スポーツにおける協調と共感 :

横山慶子（名古屋大学）

2. 協調と共感の起源一ヒトとチンパンジーにおけ るリズム同調の比較— :

服部裕子（京都大学霊長類研究所）

3. Embedded Dynamics of Social-Motor Coordina- 
tion :

Michael J. Richardson \& Rachel W. Kallen（Department of Psychology, Macquarie University, Australia)

、日本体育学会第 69 回大会体育心理学専門領域 キーノートレクチャー

日程：平成 30 年 8 月 24,25 日

会場 : 徳島大学

テーマ：スポーツ動機づけ研究の展開と展望

司会：佐々木万丈（日本女子体育大学），阿 江美恵子（東京女子体育大学）

講演 : 藤田勉 (鹿児島大学)

テーマ:アスリートの熟達化を支える自己調整学 習のすすめ

司会：中本浩揮（鹿屋体育大学）

講演：幾留沙智（鹿屋体育大学）

、日本体育学会第 69 回大会体育心理学専門領域

ランチョンセミナー

日程:平成 30 年 8 月 25 日

会場 : 徳島大学

テーマ：「ともにあるき，ともにわらう：協調と 共感のダイナミクス」延長戦

司会：工藤和俊（東京大学）, 三浦哲都（東 京大学)

演者: 横山慶子（名古屋大学）, 服部裕子（京 都大学霊長類研究所), Michael J. Richardson \& Rachel W. Kallen (Department of Psychology, Macquarie University, Australia)

\section{運動生理学}

\section{研究誌の発行}

誌名：日本運動生理学雑誌（2冊）Adv.Exerc. Sports Physiol. (4 冊) 年 6 冊発行

発行年月日: 30 年 4 月 31 年 3 月

\section{発育発達}

\section{研究誌の発行}

誌名: 子どもと発育発達（16 巻 $1 \sim 4)$, 発育発 達研究 (79 82 号), 増刊号
発行年月日 $: 4$ 月 $\cdot 7$ 月 $\cdot 10$ 月・ 1 月・ 3 月の 1 日

\section{学会賞等の授与}

○日本発育発達学会 最優秀研究賞 ・優秀研究賞 （※論文題目等：受賞者の氏名・所属）

思春期前期の子どもの身体活動，抑うつ傾向，首 尾一貫感覚（SOC）の関係：

川勝佐希（神戸大学大学院）

児童の学業成績に対する出身家庭の独自関連性一 個人内要因の統計的制御による推定一：

$$
\text { 高木誠一（国際武道大学） }
$$

\section{研究会・講演会}

○日本発育発達学会第 17 回大会

日程：平成 30 年 3 月 9 日・ 10 日

会場：大妻女子大学

\section{○学会長講演}

アジアの山地民，狩猟採集民の子どもはどのよう に育つのか一発育発達科学研究の 45 年一:

大澤清二（大妻女子大学，日本発育発達学会 会長)

\section{○教育講演 1}

健康? 元気！：

北川薰（梅村学園学事顧問, 中京大学名誉教 授）

\section{○教育講演 2}

（1）子どもの運動・スポーツ時のケガの応急処置 と緊急対応

$$
\text { 山本利春（国際武道大学） }
$$

（2）小学生における投能力向上と投球障害予防へ の取り組み

\section{笠原政志 (国際武道大学)}

(3) スポーツ心理学から考えるスポーツコーチン グ

前川直也（国際武道大学）

○シンポジウム

テーマ：測定し評価するということ一数による表 現の内と外一

（1）測定の評価

下田敦子（大妻女子大学）

(2) 評価の測定 
中川正宣（東京工業大学名誉教授）

\section{○ポスター発表}

1. 思春期の身長スパートに寄与する座高と下肢長 との関係一脚が先か座高が先か? -

$$
\text { 小林正子（女子栄養大学） }
$$

2. 中学生の体格と学業成績の関係一 2 年間の縦断 的研究一

石原暢（玉川大学脳科学研究所）

3. 子どもの「かしこい」からだの獲得と心の発達 との関連

續木智彦 (西南学院大学)

4. 思春期前期の身体活動, 座位行動, 抑うつ, 首 尾一貫感覚（SOC）の関係

川勝佐希（神戸大学大学院）

5. 小学校学習指導要領, 幼稚園教育要領における 鬼ごっこの扱いの変遷

鈴木邦明 (帝京平成大学)

6. 子どもの体力の早期決定要因一地域レベルでみ た女性の瘦せと次世代の子どもの体力一

青山友子（日本学術振興会）

7. 肉類を摂取しないカースト（ネパール）の子ど もの発育と摂取食物

中西純 (国際武道大学)

8. 都市部小学校 3 年生における活動量および体力 と生活活動時間の関連

糸井亜弥 (神戸女子大学, 国立健康 - 栄養研 究所）

9. 子どもの朝型・夜型に関連する生活要因の解明

田邊弘祐 (日本体育大学大学院博士後期課程)

10. 教室座席は子どもの睡眠状況に影響するの か?

野井真吾 (日本体育大学)

11. 観察評価による幼児の跳運動習得の順序に関 する研究

加藤謙一 (宇都宮大学)

12. 4 週間の高強度間欠的運動が小学生の体力・ 認知機能に与える影響

鳥取伸涁（立命館大学）

13. 幼児における体力の二極化とその改善方法に ついて

後藤明日香（関西学院高等部）
14. 45 分間の立ち机の利用が小学生の覚醒水準, 実行機能に及ぼす影響

田中良（日本体育大学大学院博士後期課程）

15. 睡眠状況の改善を目指した小学校での「みえ る化」実践の効果検証一 3 年間に亘る実践をも とに一

渡辺晃（日本体育大学大学院博士前期課程）

16. 走運動（短距離走）授業の指導プログラム開 発一面白くて，ためになる視点からの授業実践 を通して一

由井久満（いすみ市立長者小学校）

17. 児童の学業成績に対する運動時間の独自関連 性一その至適運動時間の検討一

高木誠一 (国際武道大学)

18. 自由遊びにおける幼児の身体活動量と基本的 な動きとの関係

篠原俊明 (東京未来大学)

19. 母子一緒の活動時間と母および幼児の身体活 動との関連

塩野谷祐子（松蔭大学）

20. 生活活動記録法を用いた幼児の登園中および 降園後の生活行動様式

秋武寛（びわこ成蹊スポーツ大学）

21. 女子小学生における体力・運動能力の個人内 格差の検討一私立 A 小学校のデータを基に一

山本晃弘（カリタス小学校）

22. 幼児の体力テストに関する世界的動向

REMILI MAIMAITIJIANG（順天堂大学大学 院）

23. 大学生女子武道選手の食の興味と競技力との 関連

中島沙織（日本女子体育大学大学院）

24. 発育期サッカー選手における膝関節軟骨の特 徵

堀明日香 (早稲田大学大学院スポーツ科学研 究科)

25. 小学生を対象とした身体活動の強度と遂行機 能に関する検討

永田康喜（日本体育大学大学院）

26. 成長期サッカー選手における発育時期と関節 弛緩性や下肢筋柔軟性は関連するか一横断的検 
討一

倉坪亮太（北里大学北里研究所病院）

27. オスグッドシュラッター病罹患児における筋 腱複合体の形態的・力学的特徵

榎本翔太 (兵庫教育大学大学院)

28. 自由遊びを中心とした園における走力の分析 西田希 (目白大学)

29. ボール投げ動作に関するキネマティクス的研

究 5 歳児と 7 歳児の比較

重松咲（奈良女子大学大学院）

30.2017 年の各月の気象と幼児の午前中の歩数と の関係

出村友寛（仁愛大学）

31. 小学校 1 年生における投の運動遊びプログラ ムに関する検討

笹倉慎吾（ミズノ株式会社スポーツ施設サー ビス事業部)

32. 休み時間における大学生の運動遊びの提供が 小学生の身体活動量に及ぼす影響

長野康平（山梨大学）

33. 踵部脂肪裖厚の経年変化と体格との関連性

前道俊宏 (早稲田大学大学院スポーツ科学研 究科)

34. 幼児期の跳動作における定位能力 ・分化能力

の発達的特性に関する研究（II）一テスト項目 間の関連に着目して一

加納裕久 (愛知県立大学)

35. 幼保施設における体を動かす活動時間の特徴 倉茂花苗（山梨大学大学院）

36.3 年間の縦断的調査による思春期前期の走速 度変化と走動作の変容

國土将平（神戸大学人間発達環境学研究科）

37. 東日本大震災の被災 3 県の保育所・こども園

における 4 ・5 歳览の運動への関わりについて

澤田美砂子（日本女子大学）

38. 児童における足機能・形態と疼痛発生リスク

および新体力テスト成績との関連性

城所哲宏（国際基督教大学）

39. タレント発掘された子どものスポーツ関連の

習い事の回数とその実施種目一埼玉県プラチナ キッズ事業で発掘された小学 4 年生を対象とし

\section{$\tau-$}

久保潤二郎 (平成国際大学)

40. 組体操遊びが幼児の閉眼片脚立位保持時間に 及ぼす影響

板谷厚 (北海道教育大学)

41. 幼児の体力と園庭環境の関係 : 事例研究

小貫凌介（順天堂大学大学院）

42. 附属中学校生徒における生活習慣及び運動習

慣に対する実態と意識調査

山本忠志 (兵庫教育大学)

43. 幼児の立ち幅跳びにおける跳躍距離獲得方略

上肢および下肢の協調性に着目して

大高千明（奈良女子大学）

44. 幼坚における走能力の測定方法として $25 \mathrm{~m}$ は 適切か?

小峯功一（順天堂大学大学院）

45. 小学校 1 年生から中学校 3 年生の体組成の特

徵や発育による変化体組成分析装置を用いて

秋原悠 (兵庫教育大学)

46. 幼児期前期の歩行を取り巻く環境に関する調 査

田中沙織（九州産業大学）

47. 鬼ごっこにおける ICT を活用したスポーツ・

リテラシー教育の展開

大㠃恵介（山梨学院大学経営情報学部)

48. 中学・高校生の背筋力指数の年次变化

小林幸次 (平成国際大学)

49. 被災地の小中学生の身体活動量に影響を及ぼ す要因に関するケーススタディ

大輪大介（東北大学大学院医学系研究科）

50. 小・中学生における体重支持に関わる下肢筋 力と運動習慣

津田好貴（国際武道武道大学大学院）

51. 都市部幼稚園 5 歳児における認知機能と身体 活動量との関係

満石寿（京都学園大学）

52. 小学校体育に活用可能な基本的動作の観察的 評価基準の作成

浅川孝太（山梨大学大学院）

53. 秩父地域小学校における総合的な学習の時間 での民俗芸能継承活動について一その現状と教 
育的効果，学習指導用要領改定の影響一

安倍希美 (北里大学)

54. 幼児におけるスクリーンタイムの持ち越しと 体力発達の関係

宮田洋之（東京福祉大学）

55. 学級での学習活動中に身体活動を取り入れた アクティブ・レッスン・プログラムの提案—シ ステマティックレビューによる研究動向の概説

喜屋武享 (琉球大学大学院保健学研究科)

56. 沖縄県の中学生における学校連結性の身体活 動への影響— 1 年間の縦断研究—

喜屋武享 (琉球大学大学院保健学研究科)

57. 看護学部生を対象とする一般教養科目「体育

II (野外活動実習)」の効果について

菊田文夫（聖路加国際大学大学院看護学研究

科・基盤領域・健康教育)

58. 幼児期の遊びが学童期の遊びに及ぼす影響

金美珍 (埼玉純真短期大学)

59. 幼児の「鬼ごっこ」における鬼の追跡からの 逃避方略

西田史西（九州大学短期大学部）

60. 小学生野球選手において側腹部筋厚に左右差 は生じていない

坂槇航 (早稲田大学大学院スポーツ科学研究

61. 男子高校生における部活動種目による体組成 と体力レベルの比較一横断的検討一

中原(権藤)雄一(福岡県立大学人間社会学部)

62. 小学生のボールゲームの戦術能力における創 造性と認知機能の関係

奥田知靖（北海道教育大学）

63. 一過性の異なる強度の運動負荷における脳波 の変動について

中島早苗（共立女子短期大学）

64. 坚童の体力, 運動, 学校生活, 学力および保 護者の子育て態度との相互関係

中野貴博（名古屋学院大学）

65. 小学 3 年生におけるジグザグドリブルと新体 カテストの男女比較

津山薰（日本体育大学体育学部）
66. 子どもの身体・文化・生活の相互作用に関す る国際比較分析の試みアジア子ども基本調査か らの報告一その 4 -

佐川哲也（金沢大学）

67. 中学生男子サッカー選手における思春期前期 のスポーツ経験の種目が下肢筋柔軟性に与える 影響

渡邊裕之 (北里大学)

68. 中学生の運動習慣およびその種類と学業成績 の関係一 2 年間の縦断的研究一

森田憲輝（北海道教育大学岩見沢校）

69. Skeletal maturity in overweight and obese children aged 3-6years old

KE DANDAN（順天堂大学大学院）

70. 保育所における幼児の身体活動量と運動能力 の関係

野中壽子 (名古屋市立大学)

71. 高校野球選手における跳躍力と投球速度の関 係

新井悠介（日本体育大学体育学部）

72. 香港日本人学校に通う子どもの生活状況

鈴木彩加（日本体育大学大学院）

73. 幼児の体力向上と身体活動量・生活習慣との 関係の検討

青木好子 (京都学園大学)

74. 中国における乳幼児教育・保育制度の現状

陳曉楠（神戸大学）

75. 「特定教育・保育施設等における事故情報デ ータベース」(内閣府）の事故誘因別からみた 年齢，性別による事故発生時の状況について

朴淳香 (静岡県立大学短期大学部)

76. 就学前児童の運動発達の特徵一体力テストの 結果と運動嗜好との関連に基づく検討一

平田香奈子（広島修道大学）

77. 短時間の補強運動でも生徒の体力は向上する のか?

小山雄三（成蹊中学高等学校） 


\section{測定評価}

\section{研究誌の発行}

誌名：体育測定評価研究（第 18 号）

発行年月日：平成 31 年 3 月 31 日

誌名：Human Performance Measurement（Vol. 15）

発行年月日:平成 30 年 4 月 1 日～(逐次論文掲載)

\section{学会賞等の授与}

\section{日本体育測定評価学会 学会賞}

（※論文題目等 : 受賞者の氏名・所属）

鍼刺激が伸張一短縮サイクル動作の遂行能力に与 える影響の評価, 体育測定評価研究 17, 55-62, 2017 :

寺田和史 (天理大学)

日本体育学会第 69 回大会 測定評価専門領域 優秀発表賞

歩行と音刺激反応を組み合わせた Multi-task test と易転倒性, MoCA 得点との関係：

山次俊介 (福井大学) ほか

高齢者における歩行および自転車移動許容距離の 規定要因に関する大規模調査 :

角田憲治（山口県立大学）ほか

大学サッカー選手におけるボールポゼッション技 能の評価方法の検討 :

山田庸（びわこ成蹊スポーツ大学）ほか

CPS を基準とした認知機能評価に関連する高齢者 の身体機能の特定一亀岡スタディー：

吉田司（国立健康・栄養研究所）ほか

日本体育測定評価学会第 18 回大会「優秀発表賞」 高齢者の道路横断時安全行動特性と筋応答の関連 性：

坂口雄介（新潟大学院）ほか

TrackMan データを用いた機械学習手法による球 種の分類とその特徵分析：

梅村和弘（早稲田大学院）ほか

項目反応理論を用いたバレーボールにおけるゲー 么評価項目の困難度 :

沼田薰樹（鹿屋体育大学院）ほか

柔道受身動作の観察による頭部外傷リスク評価と 頭䅡部キネマティクスとの関連：
越田専太郎 (了徳寺大学) ほか

幼児期における体力の高低と非認知機能発達特性 の違い：

後藤千穂（岐阜大学院）ほか 女子大学生における身体活動量と睡眠の質の関 係：

坂根裕美（京都薬科大学）ほか 把握運動条件反射法を用いた go / no-go 課題に よる高次神経活動型の自動判定：

板谷厚（北海道教育大学）ほか カーリングにおけるブラシの握り位置の違いがス イープの圧力および速度におよぼす影響：

宿谷奈苗（札幌国際大学院）ほか

\section{研究会・講演会}

日本体育測定評価学会第 18 回大会

日程:平成 31 年 3 月 2 日（土） 9 時 30 分 20 時, 3 月 3 日（日） 10 時〜 12 時 30 分 会場：札幌国際大学

○シンポジウム テーマ：AI（人工知能）とスポーツ

司会：小林秀紹（札幌国際大学）

1.AI で一流選手の主観を可視化する

乙部信吾（株式会社 LIGHTz）

2. AI によるカーリング戦略

山本雅人 (北海道大学)

テーマ: データが野球を変える一野球のデータ活 用最前線一

1. 野球におけるデータ活用の $5 \mathrm{~W} 1 \mathrm{H}$

神事努（國學院大学）

2.トレーニングに活かすデータ分析事例

久村浩 (読売巨人軍)

3. 野球データのメディアコンテンツとしての活用 岡田昇峰（データスタジアム）

\section{$\bigcirc$ 研究発表}

[口頭発表 セッション A1]

座長：村瀬智彦

1. 幼児期における習慣的なキャッチボール運動の 実践効果一投および捕球能力の量的変化および 質的変化に着目して一

関谷竜成（岐阜大学大学院）, 春日晃章（岐 
阜大学), 水田晃平 (岐阜大学大学院)

2. 運動遊びの局面構造分析一幼児の楽しさを重視 した測定法の提案へ向けて一

亀岡雅紀 (新潟大学大学院), 村山敏夫（新 潟大学), 坂口雄介 (新潟大学大学院), 尾山 裕介（桐蔭横浜大学）

3. アクティブ・チャイルド・プログラムの概念を 取り入れた体育授業の効果検証(1)一身体活動量 および動作に着目して一

大坪健太 (岐阜大学大学院), 春日晃章 (岐

阜大学), 佐藤善人 (東京学芸大学), 青野博 (日本スポーツ協会)

4. 小児の学習成績と運動能力および体組成の関連 について一小学生を対象とした探索的検討一

鈴木康裕 (筑波大学附属病院), 小林裕貴 (花 まる学習会コバ運動教室), 田邊裕基, 羽田 康司（筑波大学附属病院）

5. 中学校女子における体力特性と運動および体育 授業に対する嫌悪感の関連

湏口あずさ (岐阜大学大学院), 春日晃章（岐 阜大学)

[口頭発表 セッションA2]

座長：宮口和義

6. 中学校女子における運動遊びを取り入れた体育 授業の効果検証

渡邊雄介（岐阜大学大学院）, 春日晃章（岐 阜大学)

7. 新入生の学業へのつまずき感および大学に対す る不本意感と不登校傾向との関係

佐藤進（金沢工業大学）

8. 体力水準が精神的健康度に及ぼす影響は座位行 動量により媒介される一男子大学生を対象とす る階層的重回帰を用いた媒介分析一

内山応信（秋田県立大学）

9. HSCL（Hopkins Symptom Checklist）による介 護労働者と一般労働者のストレス反応

川野裕姫子 (大阪府立大学), 出村慎一（金 沢大学), 長澤吉則 (京都薬科大学), 松浦義 昌 (大阪府立大学), 濱野理香（株式会社ア ワハウス)

10. 介護予防教室の参加期間および認識・判断・
反応能力の関連

杉浦宏季, 吉村喜信, 横谷智久, 恐神正博, 野口雄慶（福井工業大学）

[口頭発表 セッションA3]

座長：松浦義昌

11. 高齢者の道路横断時安全行動特性と筋応答の 関連性

坂口雄介（新潟大学大学院）, 村山敏夫（新 潟大学), 亀岡雅紀 (新潟大学大学院), 尾山 裕介（桐蔭横浜大学）

12.リズムダンス活動を行う高齢者の縦断的体力 変化一 5 年間のデータに基づいて一

南輝良久 (岐阜大学大学院), 春日晃章 (岐 阜大学), 坂井智明 (名古屋学院大学)

13. 開眼片脚立位成就高齢者の 1 分間の動摇特性 の変動と性差

平井博志 (大阪府立大学), 出村慎一 (金沢 大学), 内田雄 (仁愛女子短期大学), 松浦義

昌, 川端悠，川野裕姫子（大阪府立大学）

14. 女性中高齢者における床反力波形パターンの 分類による足踏み動作の定量化

尾山裕介 (桐蔭横浜大学), 亀岡雅紀 (新潟 大学大学院), 坂口雄介 (新潟大学大学院), 村山敏夫(新潟大学), 原光希(猫山宮尾病院), 太田玉紀（猫山宮尾病院）

15. 生活習慣病罹患者を対象とした長期的な運動 療法が運動機能に及ぼす影響—疾患別の検討一 原光希（猫山宮尾病院メディカルフィットネ ス CUORE), 太田玉紀（猫山宮尾病院メデ ィカルフィットネス CUORE), 村山敏夫（新 潟大学), 尾山裕介 (桐蔭横浜大学)

[口頭発表 セッション B1]

座長：山田孝禎

16.AI 手法を用いた打撃結果と投球パターンの予 測

田原康寛, 松岡弘樹, 本田拓也, 山守杏奈（筑 波大学大学院), 安藤梢, 西嶋尚彦 (筑波大学) 17.TrackMan データを用いた機械学習手法による 球種の分類とその特徴分析

梅村和弘 (早稲田大学大学院), 矢内利政 (早 稲田大学), 永田靖 (早稲田大学) 
18. TrackMan と高速度カメラで計測したボールの 飛翔軌道の一致度検証と補正法の提案

加藤真未子(早稲田大学大学院), 矢内利政(早 稲田大学)

19. 野球の投球におけるボール到達位置の変動を 説明する運動力学的因子

島公嗣（早稲田大学大学院）, 矢内利政 (早 稲田大学)

20. 野球・ソフトボールにおけるボールの色が打 者のコース判定およびそれに要した時間に及ぼ す影響

小川真以, 山田孝禎 (福井大学), 泉山大貴, 李忠林 (福井大学大学院), 田井駿也, 柳澤 彰吾 (福井大学)

[口頭発表 セッションB2］

座長：山次俊介

21. 野球のバットスイングスピード，スイング動 作のキネマティクス特性およびそれらと打率と の関係

田井駿也, 山田孝禎 (福井大学), 泉山大貴, 李忠林（福井大学大学院）, 柳澤彰吾, 小川 真以（福井大学）

22. 野球のバットスイングスピードと筋力との関 係

山田孝禎, 田井駿也 (福井大学), 泉山大貴, 李忠林 (福井大学大学院), 小川真以, 柳澤 彰吾 (福井大学)

23. 日本人ラグビー選手における Lean Mass Index の妥当性について

中島徹哉（東洋大学大学院），太田千尋（慶 應義塾體育会蹴球部)，香川雅春（女子栄養 大学栄養科学研究所), 高田和子 (国立健康・ 栄養研究所), 星野佑貴（慶應義塾體育会蹴 球部)，田原茂行（慶應義塾體育会蹴球部）, 岩本紗由美（東洋大学大学院, Sports Performance Research Institute New Zealand, AUT, Auckland, New Zealand)

24. 高校サッカー選手における身体能力と体組成 の関連性について

長谷川賢典，工藤滉太，三浦大輝，井出幸二 郎(北翔大学)
25. 国体ライフル射撃選手における射撃中の足圧 中心動摇およびライフル銃口動摇の特性，およ びそれらが射撃パフォーマンスに及ぼす影響 柳澤彰吾, 山田孝禎, 山次俊介 (福井大学), 泉山大貴, 李忠林 (福井大学大学院), 田井 駿也, 小川真以（福井大学）

[口頭発表 セッション B3]

座長：中谷敏昭

26. 項目反応理論を用いたバレーボールにおける ゲーム評価項目の困難度

沼田薰樹（鹿屋体育大学大学院）, 濱田幸二, 坂中美郷, 村上俊祐, 高橋仁大 (鹿屋体育大学)

27. 表象を伴う予測的姿勢制御を運動指導現場で 捉える

村山敏夫 (新潟大学), 亀岡雅紀, 坂口雄介 (新 潟大学大学院), 尾山裕介（桐蔭横浜大学), 林容市 (法政大学)

28. 伸張性肘関節屈曲運動直後のホットパック処 置が遅発性筋痛に及ぼす効果

李忠林 (福井大学大学院), 山田孝禎 (福井 大学), 泉山大貴 (福井大学大学院), 田井駿 也 (福井大学), 小川真以 (福井大学), 柳澤 彰吾 (福井大学)

29. ストレッチングによる重心制御能力值の変化 川端悠 (大阪府立大学), 出村慎一 (金沢大 学), 松浦義昌 (大阪府立大学), 松本直也 (桃 山学院大学), 長澤吉則 (京都薬科大学), 青 木宏樹 (福井工業高等専門学校), 内田雄 (仁 愛女子短期大学)

30. 柔道受身動作の観察による頭部外傷リスク評 価と頭頝部キネマティクスとの関連一競技経験 のある柔道有段者と初心者の比較—

越田専太郎, 石井孝法 (了徳寺大学), 松田 雅弘 (城西国際大学), 橋本俊彦 (首都大学 東京）

[ポスター発表 セッションPA1]

31. 幼児における一斉および自由な活動時の活動 量と体力との関係

出村友寛（仁愛大学）

32. 幼児期の跳動作におけるコオーディネーショ ンテストの検討一動的なものに対する定位能 
力・分化能力に着目して一

加納裕久 (愛知県立大学)

33. ジャンケンのルールを用いた選択反応時間の

経年変化一年少児を対象として一

横谷智久, 野口雄慶, 杉浦宏季, 恐神正博,

吉村喜信（福井工業大学）

34. 幼児期における体力の高低と非認知機能発達 特性の違い

後藤千穂（岐阜大学大学院）, 春日晃章（岐 阜大学), 中野貴博 (名古屋学院大学)

35. 小学校低学年の体育授業における運動強度の 個人差および種目間差一運動学習場面に着目し て一

古田真太郎 (岐阜大学大学院), 春日晃章 (岐 阜大学), 小栗和雄 (岐阜聖徳学園大学), 大 坪健太 (岐阜大学大学院), 武山有香 (下米 田小学校)

36. 将棋経験を有する小児の身体能力, 体組成, 身体活動量と棋力との関連一日本将棋連盟将棋 スクールに通う小学生を対象とした探索的調査

古薗弘隆 (筑波大学附属病院), 鈴木康裕 (筑 波大学附属病院), 駒野茂（日本将棋連盟）, 羽田康司（筑波大学附属病院）

37. 保護者の運動志向性は子ども達の運動意欲や 体力変化に影響をおよぼすのか一実践的取り組 みにおける子ども達の様子を通して一

中野貴博, 赤池穂奈美, 山田妃南乃（名古屋 学院大学), 春日晃章 (岐阜大学)

38.3 年間の保育現場への体力 ・運動能力の測定 支援による評価資料作成の試み

村瀬智彦 (愛知大学), 早川健太郎 (名古屋 経営短期大学), 岡本浄実 (京都文教大学)

39. 小学校の水泳授業における運動強度に関する 研究一泳力差が及ぼす影響に着目して一

鈴木裕貴 (岐阜大学大学院), 春日晃章 (岐 阜大学), 小長谷研二 (岐阜大学大学院)

40. アクティブ・チャイルド・プログラムの概念 を取り入れた体育授業の多角的効果検証(2)一体 育に対する意識に着目して一

東健司 (岐阜大学大学院), 春日晃章 (岐阜
大学), 佐藤善人 (東京学芸大学), 青野博 (日 本スポーツ協会), 大坪健太(岐阜大学大学院) [ポスター発表 セッションPB1]

41. 中学校運動部生徒における足部形状, 足圧分 布および足指間筋力について

宮口和義（石川県立大学）

42. 運動習慣のない一般学生のステップ反応テス トの反応時間の性差

松浦義昌 (大阪府立大学), 出村慎一 (金沢 大学), 松本直也 (桃山学院大学), 吉村雅文(順 天堂大学), 当麻成人 (大阪薬科大学), 濱野 理香（株式会社アワハウス）

43. 女子大学生における身体活動量と睡眠の質の 関係

坂根裕美 (京都薬科大学), 沼尾成晴 (鹿屋 体育大学), 長澤吉則 (京都薬科大学)

44. 陸上競技の授業における予測值と実測值の差 大川昌宏（常葉大学）

45. 大学生の BMI と体力に関する検討一瘦せと肥 満, 標準体重者の体力特性一

酒井俊郎（中部大学）

46. 若年者の下肢等尺性筋力発揮調整能と歩行能 力及び認知機能の関係

長澤吉則, 進藤聡人 (京都薬科大学), 沼尾 成晴 (鹿屋体育大学), 出村慎一 (金沢大学), 青木宏樹（福井工業高等専門学校）

47. 連続選択反応テストにおける新たな刺激提示 パターンの検討

藤原未稀（京都薬科大学）, 沼尾成晴（鹿屋

体育大学), 長澤吉則 (京都薬科大学)

48. 連続選択反応テストの試行間差の検討

青木宏樹 (福井工業高等専門学校), 出村慎 一 (金沢大学), 内田雄 (仁愛女子短期大学), 平井博志 (大阪府立大学), 当麻成人 (大阪 薬科大学)

49. 若年者サッカー選手を対象としたフィットネ スに対する相対的年齢効果

高木靖弘, 小林秀紹 (札幌国際大学)

[ポスター発表 セッションPA2]

50. 体力テストへの喫煙習慣の影響一体力テスト 評価への影響と心拍変動一 
武藤三千代（日本医科大学），勝又聖夫，平 田紀美子，佐藤麻衣子，稲垣弘文，川田智之 (日本医科大学)

51. 体力テストへの喫煙習慣の影響一体力テスト 前後の唾液中カテコールアミン代謝物等の測定

平田紀美子, 勝又聖夫, 佐藤麻衣子, 稲垣弘文, 川田智之(日本医科大学衛生学・公衆衛生学), 武藤三千代 (日本医科大学スポーツ科学)

52. 若年者におけるストレッチングが起立負荷の 自律神経系機能に及ぼす影響

藤井浩子, 長澤吉則 (京都薬科大学), 沼尾 成晴 (鹿屋体育大学)

53. 把握運動条件反射法を用いた go/no-go 課題に よる高次神経活動型の自動判定

板谷厚 (北海道教育大学), 鹿野晶子（日本 体育大学), 野井真吾 (日本体育大学)

54. 青年男性および女性の静止立位時における足 圧中心動摇評価変数の分布特性

当麻成人 (大阪薬科大学), 出村慎一 (金沢 大学), 松浦義昌 (大阪府立大学), 長澤吉則 (京都薬科大学), 青木宏樹 (福井工業高等専 門学校), 川端悠（大阪府立大学）

55. 地域在住高齢者の転倒リスクと軽度認知障害 を捉える身体機能テストの検証

山次俊介 (福井大学), 石原一成 (福井県立 大学), 佐藤敏郎 (新潟医療福祉大学)

56. 移動をともなうジャンプ・トレーニングが高 齢者の下肢筋機能に及ぼす影響

中谷敏昭 (天理大学), 木野和樹（天理大学 大学院)

57. 雨天日の高齢女性の身体活動

坂井智明（名古屋学院大学）

58. 介護予防運動機能向上標準プログラム（大分 県版）の性別，年代別，家族構成別の効果

稲垣敦（大分県立看護科学大学）

[ポスター発表セッションPB2］

59. カーリングにおけるブラシの握り位置の違い がスィープの圧力および速度におよぼす影響

宿谷奈苗（札幌国際大学大学院），小林秀紹 (札幌国際大学)
60. ソフトテニスのグラウンドストロークにおけ る精度と打球速度の測定法一エリート選手を対 象として一

高橋憲司（愛知学泉大学）, 篠原秀典，山口 大地 (日本体育大学), 緒方貴浩 (帝京大学), 永野康治（日本女子体育大学）高橋和孝（筑 波大学大学院）井田博史（上武大学）

61. カヤック選手のエルゴメーターで計測した漕 パワー発揮值と漕タイムの関係一上位選手と下 位選手の比較一

野口雄慶, 横谷智久, 杉浦宏季, 朱光珍（福 井工業大学), 北林保 (東京理科大学)

62. アルペンスキー競技に求められる最大無酸素 パワーの発揮特性を考慮した評価法

星野宏司（北星学園大学）

63. 若年男性における動脈スティフネスと柔軟性 の関係

松本望（京都薬科大学），沼尾成晴（鹿屋体 育大学), 長澤吉則 (京都薬科大学)

64. 各種立位姿勢の観察評価と閉眼片脚立位時の 重心動摇および姿勢保持時間の関係

内田雄（仁愛女子短期大学），出村慎一（金 沢大学), 長澤吉則 (京都薬科大学), 川野裕 姫子 (大阪府立大学), 平井博志 (大阪府立 大学)

65. 伸張 - 短縮サイクル（SSC）を用いたジャン プテストの方向間（前・後）の比較

北林保（東京理科大学）

66. ウォーミングアップ時の下腿へのフロスバン ドによる圧迫が各種の運動パフォーマンスに及 ぼす急性影響

寺田和史, 奥祐樹 (天理大学), 兼安亜美, 平元香葉，松本健二，川上晃司（天理大学大 学院), 中谷敏昭（天理大学）

67. 画像解析ソフト ImageJ を用いた膝関節角度の 信頼性検証

金興烈 (南山大学), 稲嶋修一郎 (愛知県立 大学), 高橋和文 (金城学院大学), 村本名史 (常葉大学)

\section{○の他}


研究助成事業 : 1 件の研究題目の研究代表者に助 成を実施

日本体育学会第 69 回大会における「統計相談 コーナー」の設置

\section{体育方法}

\section{研究誌の発行}

誌名：コーチング学研究 (31 巻 2 号)

発行年月日: 平成 30 年 3 月

誌名：コーチング学研究 (32 巻 1 号)

発行年月日：平成 30 年 10 月

\section{学会賞等の授与}

\平成 29 年度日本コーチング学会 学会賞

（※論文題目等：受賞者の氏名・所属） サッカー選手のチーム戦術に対する認識の検討：

小圷昭仁（防衛大学校）

平成 29 年度日本コーチング学会 奨励賞

ハンドボール競技における強豪国と日本の一貫指 導プログラムに関する比較研究：

永野翔大（筑波大学大学院）

จ平成 30 年度日本コーチング学会 奨励賞 遠征型キャンプが小中学生の自然に対する態度に 及ぼす効果：滞在型キャンプ及びキャンプ不参加 者との比較：

岡田成弘（仙台大学）

一流走高跳選手のパフォーマンス向上過程におけ る事例研究 :

戸邊直人（筑波大学大学院）

日本コーチング学会第 30 回学会大会優秀発表賞 超速球を見るトレーニングが打撃パフォーマンス に及ぼす即時効果：

中島大貴（中京大学大学院）

わが国のプロ野球捕手における二塁送球動作の定 量的かつ定性的特徴分析：

梶田和宏（筑波大学大学院）

運動意識の発生分析から得られる実践知の活用に 関する研究：

田川浩子（鹿屋体育大学）

大学女子バスケットボール選手が自主的に課題解
決策を考えてトレーニングに取り組む手法の考案 と成功事例：

小原侑己（鹿屋体育大学）

床運動におけるひねり技に関する指導法の研究：

針谷理栄子（日本体育大学大学院）

スポーツ指導者コンピテンシーを可視化する客観 的評価テスト $(\mathrm{SCCOT})$ の開発 :

近藤亮介（鹿屋体育大学）

\section{研究会・講演会}

、日本コーチング学会第 30 回学会大会・第 12 回日本体育学会体育方法専門領域研究会

日程：平成 31 年 3 月 13 日一 14 日

会場 : 東海大学湘南キャンパス

○基調キーノートレクチャー

演題 : ハイパフォーマンススポーツにおけるコー チング

演者:久木留毅（国立スポーツ科学センター） ○ワクショップ

演題 : 種目間横断的連携による競技力向上に向け た実践

第 1 部：種目間連携の取り組み事例報告

第 2 部：戦術力向上へのコーディネーショントレ ーニングの応用

演者: 栗山雅倫 (東海大学), 藤井壮浩 (東 海大学), 小山孟志 (東海大学), 八百則和 (東 海大学), 小西康仁 (東海大学)

○シンポジウム

テーマ:クリエイティブ・コーチングを考える

コーディネーター：會田宏（筑波大学）

シンポジスト：

コーチングにおける一人称と二人称

諏訪正樹（慶應義塾大学

コーチの学びを支援する

伊藤雅充（日本体育大学）

コーチングの真髄を求めて

大村邦英 (日本体育大学)

○ラウンドテーブル・ディスカッション

演題：東海大学におけるコーチング「東海メソッ

ド」の取り組み

話題提供: 加藤健志 (東海大学), 上水研一朗 (東 
海大学), その他

\section{保健}

\section{学会賞等の授与}

（一社）日本体育学会保健専門領域 発表賞

（※論文題目等：受賞者の氏名・所属）

謎解きウォーキングが Life Skills の形成に与える 影響 :

山田浩平（愛知教育大学）

就労者に対する体操法・呼吸法・睻想法によるヨ 一ガ療法介入の効果検討：

村上真 (筑波大学)

実習校との連携・協同による保健体育科教育実習 の効果的な実習プログラム開発のための基礎的研 究:

長岡知（順天堂大学）

\section{研究会・講演会}

第 2 回保健授業づくり公開フォーラム

日程：2019年 3 月 17 日（日）

会場 : 筑波大学東京キャンパス 1 階 120 教室

\section{$\bigcirc$ 基調講演}

新学習指導要領に基づく保健の授業の考え方と進 め方一高等学校に焦点を当てて一

横嶋剛（スポーツ庁）

○研究報告

保健授業の実践研究の現状と課題

横嶋剛（スポーツ庁）

実践報告

放射線と健康の授業実践について

國川聖子（筑波大学附属中学校）

\section{スポーツ人類学}

\section{研究会・講演会}

2018 年度第 1 回日本体育学会スポーツ人類学 専門領域研究例会

日程：平成 30 年 11 月 10 日（土）

会場：関西大学千里山キャンパス社会学部社会調 查実習室 B201

\section{【話題提供】}

1. 越境の野球史一日米スポーツ交流とハワイ日系 二世：

森仁志（関西大学人間健康学部人間健康学科 准教授)

2. ディアスポラ・ブラジリアンにとってのアイデ ンティティ構築の装置としての日系スポーツ= 野球:

石原豊一（スポーツ社会学研究家・高校教員）

\section{アダプテッド・スポーツ科学}

\section{研究誌の発行}

誌名：アダプテッド体育・スポーツ学研究（第 4 巻 1 号)

発行年月日：平成 31 年 3 月 31 日

\section{学会賞等の授与}

・アダプテッド・スポーツ科学専門領域研究奨励 賞（口頭発表部門）

（※論文題目等：受賞者の氏名・所属）

ブラインドサッカー選手の音源方向を定位する早 さに関する検討：

三枝巧(筑波大学大学院人間総合科学研究科)

・アダプテッド・スポーツ科学専門領域研究奨励 賞（ポスター発表部門）

アダプテッド体育・スポーツ小学校のインクルー シブ体育における指導体制による授業成果の特 徵 :

荻原大河（猪名川町立白金小学校）

\section{研究会・講演会}

○日本体育学会第 69 回大会アダプテッド・スポ

ーツ科学専門領域企画シンポジウム 2018 年 8 月 25 日

テーマ：大学におけるアダプテッド・スポーツ教 育 その 2

岩見沢における大学を中心としたアダプテッド・ スポーツ振興の取り組み

大山祐太 (北海道教育大学)

地域スポーツの核となりうるアダプテッド・スポ 
ーツの普及・推進を目指して

井上明浩 (金沢星棱大学)

西九州大学における地域との互恵関係によるアダ プテッド・スポーツ教育について

山田力也（西九州大学）

\section{その他}

・アダプテッド・スポーツ科学専門領域，活動支 援助成金事業

地域の専門領域活動の活性化を目的としたアダ プテッド・スポーツ科学に関する研究会, 研修会, 情報交換会など地域における本専門領域会員が参 加できる活動を対象に実施している。2018 年度 は下記の 3 件が採択された。

1. 東海大学アダプテッド・スポーツ研究会（内 田匡輔)

2. つくりんピック 2018 実行委員会（清水哲大）

3. 筑波技術大学障がい者のためのスポーツイベ ント実行委員会（向後佑香）

\section{介護福祉・健康づくり}

\section{研究誌の発行}

誌名：介護予防・健康づくり（3 巻 1,2 号)

発行年月日：平成 30 年 6,12 月

\section{研究会・講演会}

、日本介護予防・健康づくり学会

会場 : 早稲田大学

○大会長講演：
ローイング (ボート漕ぎ) 運動による介護予防と 健康づくり

樋口満（早稲田大学スポーツ科学学術院） $\bigcirc$ 特別講演 :

高齢者の生活リズムと健康一時間栄養・運動学か らの提言一

柴田重信 (早稲田大学先進理工学部)

超高齢社会におけるロボット工学の役割

藤江正克 (早稲田大学名誉教授)

\section{基調講演 :}

長寿社会に生きる

秋山弘子（東京大学高齢社会総合研究機構） 高齢者の食欲と健康一グレリン発見者からの提言 -

児島将康（久留米大学分子生命科学研究所） ○シンポジウム：

超高齢社会におけるスポーツ医科学の役割一メタ ボとロコモの予防一

岡浩一朗 (早稲田大学スポーツ科学学術院), 伊藤智子 (早稲田大学スポーツ科学学術院), 渡辺尚彦（東京女子医科大学東医療センタ 一), 鈴木克彦 (早稲田大学スポーツ科学学 術院)

超高齢社会におけるライフスタイルと健康一アク ティブ・ライフの社会実装化一

村田太一郎 (ウォーキングクラブ GNP), 竹 宇治聡子（ローマオリンピック競泳メダリス ト), 北居和夫 (ボート団塊号), 小関信行 (日 本クアオルト研究機構), 荒木邦子 (ワセダ クラブ 2000) 